\title{
INDUSTRIAL CLUSTERING AND ECONOMIC PERFORMANCE. IN SEARCH FOR EVIDENCE FROM POLAND
}

\author{
Jakub Kwasny ${ }^{1, a}$, Arkadiusz Mroczek ${ }^{2, b, *}$ and Marta Ulbrych $^{3, c}$ \\ ${ }^{1}$ Department of International Economic Relations, Cracow University of Economics, Poland \\ ${ }^{2}$ Department of International Economic Relations, Cracow University of Economics, Poland \\ ${ }^{3}$ Department of International Economic Relations, Cracow University of Economics, Poland \\ akwasnyj@uek.krakow.pl, bmroczeka@uek.krakow.pl, culbrychm@uek.krakow.pl \\ *Corresponding author
}

Cite as: Kwasny, J., Mroczek, A., Ulbrych, M., (2019). Industrial clustering and economic performance. In search for evidence from Poland, Ekonomicko-manazerske spektrum, 13(1), 109-119.

Available at: dx.doi.org/10.26552/ems.2019.1.109-119

\begin{abstract}
The aim of the paper is to examine the effects of clustering industrial activity in some selected regions of Poland. Industrial clusters are recognised to be core entities of economic growth and innovation in the global economy (Njøs and Jakobsen, 2016). As theoretical considerations suggest, industrial clusters understood as a concentration of specific kinds of industry in particular locations generate some positive externalities. The companies belonging to those industries may benefit from the fact that they are spatially concentrated. To determine the existence of such externalities, the data on industrial value added per working person, GDP per capita and GDP growth was used as indicators of the condition of the economy in particular area (NUTS 3 level). Then it was confronted with the results of own research on industrial clusters to determine whether the latter may be a source of competitive advantage of the area. The existing studies dealing with industrial clusters mainly use the case study method or quantitative approach based on one particular cluster. In this paper, a more general approach is used and it tries to identify the influence of clusters on economies on a broader level. The results show that on one hand, no connection between the cluster creating and value added was revealed, on the other hand, the connection with both GDP per capita and GDP growth was shown.
\end{abstract}

Keywords: industrial clusters, externalities, economic growth, value added

JEL Classification: JL16, L60, O14, O18

\section{Introduction}

The aim of this paper is to examine the effects of clustering industrial activity in some selected regions of Poland. The research focuses on determining externalities of clusters using the data on industrial value added per working person, GDP per capita and GDP growth. This broader, macroeconomic way, the approach supports the value added of this paper. To explain the research and its results, some literature review in the field of the studied phenomenon is first performed and then the empirical part is described. The article ends with a discussion and conclusions. 
The question of industry location and its organisation has been present in literature for decades (Press, 2006; Vicente, 2018). Basically, the subject is analysed in the framework of economic geography. This broadly ranging discipline of science seeks to study, describe and explain the location, distribution and spatial organisation of economic activities at different levels (local, regional and national economies). This field of research is particularly interesting today, due to the globalisation of economic activities that has been strongly observed since the 1980s. Paradoxically, the global economy simultaneously exhibits trends towards both increasing globalisation and localisation. Functioning within the global market and coping with the pressure of international competition is a challenge for enterprises, especially small and medium-sized. In this context, the literature identifies, inter alia, location in a geographic cluster of networked companies as a source of competitive advantage. The geographic concentration of companies builds the value of those firms by enabling them to cooperate and to use highly specialized local supply, services, etc. And even if it also forces them to deal with strong local competition, it makes them stronger on the broader market. Factors determining production costs are, in theory, sub-divided into two groups. Citing the study of Capello (2009), it can be said, that these factors can be exogenous or endogenous to the local context. The first group includes elements such as the casual local presence of a dominant firm or a multinational company, the diffusion in the area of innovation produced elsewhere or implementation of new infrastructure decided by external authorities. The second set of conditions arise and develop locally and enable the area to initiate a process of selfpropelling development (i.e. entrepreneurial ability, local factors of production and the decision-making capacity of local authorities or system of local governance). Interactions between local companies are a form of externalities, which are central to all location analyses. According to Henderson (1997), companies cluster together at various locations to receive information spilling over from other firms, to reduce transport costs of interfirm trade and to enhance the diversity of firms and local products available. Awareness of those conditions can be a factor motivating more and more companies to locate in a cluster.

A more in-depth and chronological literature review should begin with the late 19th century. It was then, when Alfred Marshall, in the book Principles of Economics (1890) identified and discussed the phenomenon of "the concentration of specialised industries in particular localities.". He described them as industrial districts (historically tied socioterritorial entities). The theory was the first to conceptualize external economies (of agglomeration) as a source of territorial competitiveness. In Marshall's view, industrial location closely linked to proximity favours the intra-industry collaboration, reduces transport costs of input/output and allows firms to benefit from a more specialized and efficient labour market. Such externalities are called Marshall's or localisation economies.

Marshall's description of industrial districts was used to support the argument that local agglomerations of the industry can produce external economies and efficiency improvement. Naturally, along with progress in economics, the theory of local endogenous development has evolved. During the 1970s, studies on bottom-up processes of district development were especially intensive and brought a notion of diversified-relational space and its importance. This interest was caused, above all, by the emergence of new industrial regions based on hightechnology activities. According to Capello (2009) in that period a radical change in the conceptualisation of space took place. It was identified as an economic resource and independent factor of production. Particular space (also referred to as territory) can be a generator of static and dynamic advantages for firms and a key determinant of local production systems' competitiveness. Research in this area was continued in the following 
decades by Arrow (the 1960s) and Romer (the 1980s) and became known as the MarshallArrow-Romer (MAR) model. This model claims that the concentration of an industry in a region stimulates knowledge spillovers between companies. It also facilitates innovation in this particular industry within the region, as stated by Beaudry and Schiffauerova (2009).

Meanwhile, to some extent a contrary view was presented by Jacobs (1969), who pointed out that not the concentration of particular industry in a place, but the variety of industries promotes the exchange of knowledge and information flow and, consequently, innovation and economic growth. As such diversity is possible only in big cities, this approach is often called urbanisation economies or Jacob's externalities. As a result, some of the scholars' interest was shifted to the role that a city plays in agglomeration economies.

Nevertheless, as Shaver and Scott (2002) wrote, the phenomenon of industrial districts has received increasing attention as an alternative (based on small and medium-sized enterprises) to large corporations in early 1980. For instance, Eriksson (2011) in his study points out the Becattini research, which expanded the analysis to a broader perspective including the social, cultural and institutional foundation of the local economy and industry. Becattini (1989) defines industrial districts as "a particular growth type of agglomeration, characterised by a localised thickening of inter-industrial relationships which is reasonably stable over time." Thus, a functioning network of firms in a district is an essential element of such a locality.

Table 1: Selected studies on clusters

\begin{tabular}{|c|c|c|c|}
\hline Literature approach & Key elements & Type of externalities & \\
\hline $\begin{array}{l}\text { Marshall (1890) } \\
\text { Industrial districts }\end{array}$ & $\begin{array}{c}\text { Forces that drive agglomeration: } \\
\text {-access to natural resources and } \\
\text { transportation, } \\
\text {-labour pooling, } \\
\text {-share of middle suppliers, } \\
\text {-knowledge spillovers. }\end{array}$ & $\begin{array}{l}\text { Localisation } \\
\text { Agglomeration advantages for companies } \\
\text { spatially concentrated and in the same industry } \\
\text { or conducting similar types of activities. } \\
\text { Companies benefit from co-location due to the } \\
\text { creation of a regional stock of specialised } \\
\text { inputs. }\end{array}$ &.$\varrho$ \\
\hline $\begin{array}{l}\text { Jacobs (1969) } \\
\text { Jacobs' externalities }\end{array}$ & $\begin{array}{l}\text { Economic diversity is the key to } \\
\text { urban prosperity. Different industries } \\
\text { complement each other in the } \\
\text { creation of innovations through } \\
\text { knowledge spillovers across } \\
\text { industries. }\end{array}$ & $\begin{array}{l}\text { Urbanisation } \\
\text { Agglomeration advantages occur in large cities } \\
\text { as a consequence of their rich and diversified } \\
\text { economic environment (highly skilled } \\
\text { workers, specialised services) and access to } \\
\text { advanced infrastructure. }\end{array}$ & 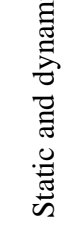 \\
\hline $\begin{array}{l}\text { Becattini (1989) } \\
\text { New industrial districts }\end{array}$ & $\begin{array}{l}\text { Industrial district as socio- } \\
\text { geographic entities which are } \\
\text { characterised by the active presence } \\
\text { of both community of people and } \\
\text { population of firms in one naturally } \\
\text { and historically tied area. }\end{array}$ & $\begin{array}{l}\text { Localisation } \\
\text { Governance structures and external economies } \\
\text { in terms of information flow, knowledge } \\
\text { spillovers, and links with suppliers and buyers. }\end{array}$ & \\
\hline $\begin{array}{c}\text { Porter }(2000) \\
\text { Clusters }\end{array}$ & $\begin{array}{l}\text { The effects of competition on } \\
\text { innovation and growth. }\end{array}$ & $\begin{array}{l}\text { Localisation } \\
\text { Highly competitive climate induces firms to } \\
\text { innovate. Knowledge spillovers take place } \\
\text { mainly among firms belonging to the same } \\
\text { vertically integrated industry. }\end{array}$ & 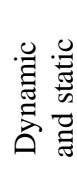 \\
\hline
\end{tabular}

Source: compilation by authors based on Komorowski (2016), Lucio et al. (2002) and Pessoa (2011).

Although the discussion of local industrial systems has a long history, Porter's definition of a cluster is perhaps most often used. According to Porter (2000), "clusters are geographic concentrations of interconnected companies, specialized suppliers, service providers, firms in related industries, and associated institutions (e.g., universities, standards agencies, trade associations) in a particular field that compete, but also cooperate." The central hypothesis is 
that a cluster is a system of interconnected firms and institutions whose whole is more than the sum of its parts.

The above, necessarily abbreviated review, leads to a statement that there is strong theoretical support for the existence of external economies of scale limited in their industrial scope (see table 1). According to the theories, space is a source of increasing returns and of positive externalities taking the form of localisation economies. Higher growth rates can be achieved by local industrial systems due to their production efficiency. They provide a reduction in production and transaction costs, higher efficiency of the other production factors and an increase of innovation capacity. Both the traditional and the more recently developed typologies of linkages are described by Nachum and Keeble (2003). The main external linkages, identified by them, include the labour market, external supply of intermediate inputs, interaction with customers, networking, collaboration and competition with firms other than customers or suppliers and collective learning together with creativity. Furthermore, the agglomeration externalities are both static and dynamic. The first type affects the productivity of companies through an increase in the efficiency of technologies in use (such as transportation and transaction costs reduction). The dynamic externalities are associated with knowledge flows and diffusion, and thus they can influence the relative well being of regions in the long run, which is stressed, among others, by Pessoa (2011).

To clarify this topic further, another reference to Porter (2000) can be made. According to him, clusters affect competition in three ways, through:

- increasing the current (static) productivity of constituent firms or industries,

- increasing the capacity of cluster participants for innovation and productivity growth,

- stimulating new business formation that supports innovation and expands the cluster.

Having said this, it is also worth to mention that not all spatial agglomerations of small firms in the same or similar sectors necessarily form a local industrial system (a cluster). In accordance with Pessoa (2011), it is important to first underline that a key characteristic of a cluster is interdependence among firms. However, this interdependence is not a sufficient condition for classifying any network of companies as a cluster. For a network of firms, to be classified as a cluster, not only a certain common interest, is necessary. An additional condition is an inclusive character that allows non-members to benefit from external economies that spill over to organisations localised under cluster influence. Another issue analysed by many authors, including Callois (2008), is the question of proximity. It is understood traditionally as geographical closeness, but also as a prerequisite for interconnections and relations between companies. Porter (2000) emphasizes that proximity, arising from the co-location of companies, customers, suppliers, and other institutions, amplifies all of the pressures to innovate and upgrade.

Another important issue, discussed by several authors, is the ability of a local economic system to generate conditions for long-lasting development. It is connected with finding a specific place in the international division of labour, through efficient use of resources. Traditionally, close geographic proximity was regarded as critical for the intensification of externalities. Some recent studies point out, however, that external linkages of firms may not always be confined only to their immediate environment. In reply to the globalisation of competition, and the need to gain benefits of scale by responding to international demand, firms can extend the geographic scope of their external linkages (Nachum and Keeble, 2003). Admitting this, it is worth to recall the study of Belleflamme et al. (2000). They support more 
traditional conclusions and suggest that that local agglomeration is even more likely to occur in the global economy. Localisation economies can produce externalities that enable the companies to sell substantial fractions of their output on distant markets.

Summarizing the literature review, it should be emphasized that the problem of clusters is intensively discussed in the studies of researchers. It is worth mentioning Cruz and Teixeira (2009) research, which indicates a growing interest in this subject, especially in the last 3 decades. Authors stress three of its most relevant elements. The first analyses geographical proximity, which generates agglomeration economies through internal specialisation and the division of labour. The next scope is related to social networks and knowledge transmission. The importance of this element is increasing due to the fact, that technological change provides the decline of routine employment in favour of the growth in social skill intensive employment (Deming, 2017). While the third component takes into account the business atmosphere and informal ties. All the mentioned conditions and channels affect the dynamics of cluster development, which should strengthen the development of the region.

\section{Methodology}

The first studies on clusters, like the one done by Marshall, were based on observation of reality in the mode that could nowadays be classified as case studies and qualitative research. Combined with more universal concepts, like economies of scale and externalities, they provide an important insight not only into regional economics but also to the development and economic growth theory. Attempts to do more quantitative research have also been made. In an example of this approach, the authors (Midelfart-Knarvik and Steen, 1999) were able to show the existence of externalities on a relatively low level of aggregation, that they call "subclusters." At the same time, they found no evidence on the total industry level they were investigating (Norwegian maritime industry). Also, Basu and Fernald (1995) point out at methodological difficulties in measuring externalities based on value-added data. Nevertheless, further examples of this kind of studies - based on one strictly defined industry can be pointed out. Some recent of them are: Jevwegaga et al. (2018) relying on qualitative research, Pandit et al. (2018) dealing with the financial sector, Lyu et al. (2017) performing research on the mobile industry (2017), Hervas-Oliver (2017) researching ceramic industry, Rodriguez-Victoria (2017) hotel industry. Liu et al. (2019) performed a research on partnerships between knowledge-intensive business services and product companies in Bremen, Qi et al. (2019) studied e-commerce industry in China and Beciuini and Pisano (2018) showed how for some industries clustering was a way to survive global competition. In this paper, an attempt to research on a more general level is described, which is rarer to be found in the literature.

The basic idea of this research is as follows. Both qualitative studies and some quantitative analyses point out at the existence of the cluster driven externalities at the micro level, i.e. that of geographically concentrated and relatively narrowly defined industries. Those externalities could be then visible also at mezzo or macro-economic level. That means that those geographic units that are characterized by strong clustering phenomena, could be more economically vivid than others could. Even if it would be too much to expect that clustering is the main reason behind the economic success of a place, it should at least play its part in it.

In order to perform the study, 25 NUTS 3 areas from all the five southern regions of Poland (Podkarpackie, Małopolskie, Śląskie, Opolskie, Dolnośląskie) where chosen as the objects. The objects are different in structure, industrialization and economic history; they include 
both big cities as well as periphery areas and in total, they represent about $1 / 3$ of the Polish economy in terms of GDP creation. All of this makes them appropriate for statistical research.

Then a database was created in which the data on the clusters existing in those areas was stored. Each cluster was marked according to the industry it belongs to and for all of the clusters the number of belonging companies was also stored. This was recognized as important, as it represents, to some extent, the variety of intracompany interactions and the range of possible choices of subcontractors, etc. In other words, the more companies belong to a cluster, the higher importance was ascribed to it. The total number of companies belonging to all the clusters in each area was also calculated, to show clustering activity of the areas. This number is here referred to as "the clustering factor." In total, 75 clusters, with 3,170 companies, were found, and big differences between areas in this field were revealed, as the number per each ranged from 0 to 14 entities. The clusters were classified according to their main industrial activity to manufacturing and technology, ICT, agriculture and trade, energy and construction, leisure and health industry. Websites of the formal associations of entrepreneurs, and the companies - cluster members, as well as local authorities were the main source of the information. It is necessary to admit, that the research that was performed probably did not reveal all the geographic concentrations of companies, but the results can be considered informative enough. First of all, because of some European grants that used to support cluster initiatives, a lot of possible clusters materialized formally by creating associations, for which the data was collected. In spite of this, it should be assumed, out of caution, that the database does not consist of the economically active clusters. Nevertheless, it still forms a reliable research sample, as there should not be any systematic error in it.

The study also uses secondary data collected from the Central Statistical Office of Poland (GUS) on Gross Value Added (GVA) per worker, Gross Domestic Product per capita (GDP) and GDP growth for NUTS 3 areas. The method used is correlation analyses, which was technically performed by MS Excel Data Analysis Toolpack. For the 25 areas (objects) the correlation of the "cluster factor" with the GVA per worker (GVA p.w.), GDP per capita (GDP p.c.) and GDP growth was calculated. Further correlations for widely defined industries were also checked. This procedure was executed to test the three following hypotheses. There is a relation between industrial clustering in a region and: 1) GVA per worker, 2) GDP per capita level and 3) GDP growth.

\section{Results}

The findings in terms of the clustering factor are visualised in Figure 1. The size of the circle corresponds to the value of the factor. The figure shows a map of the part of Poland in question, in division into NUTS 3 areas. 
Figure 1: Distribution of the clustering factor

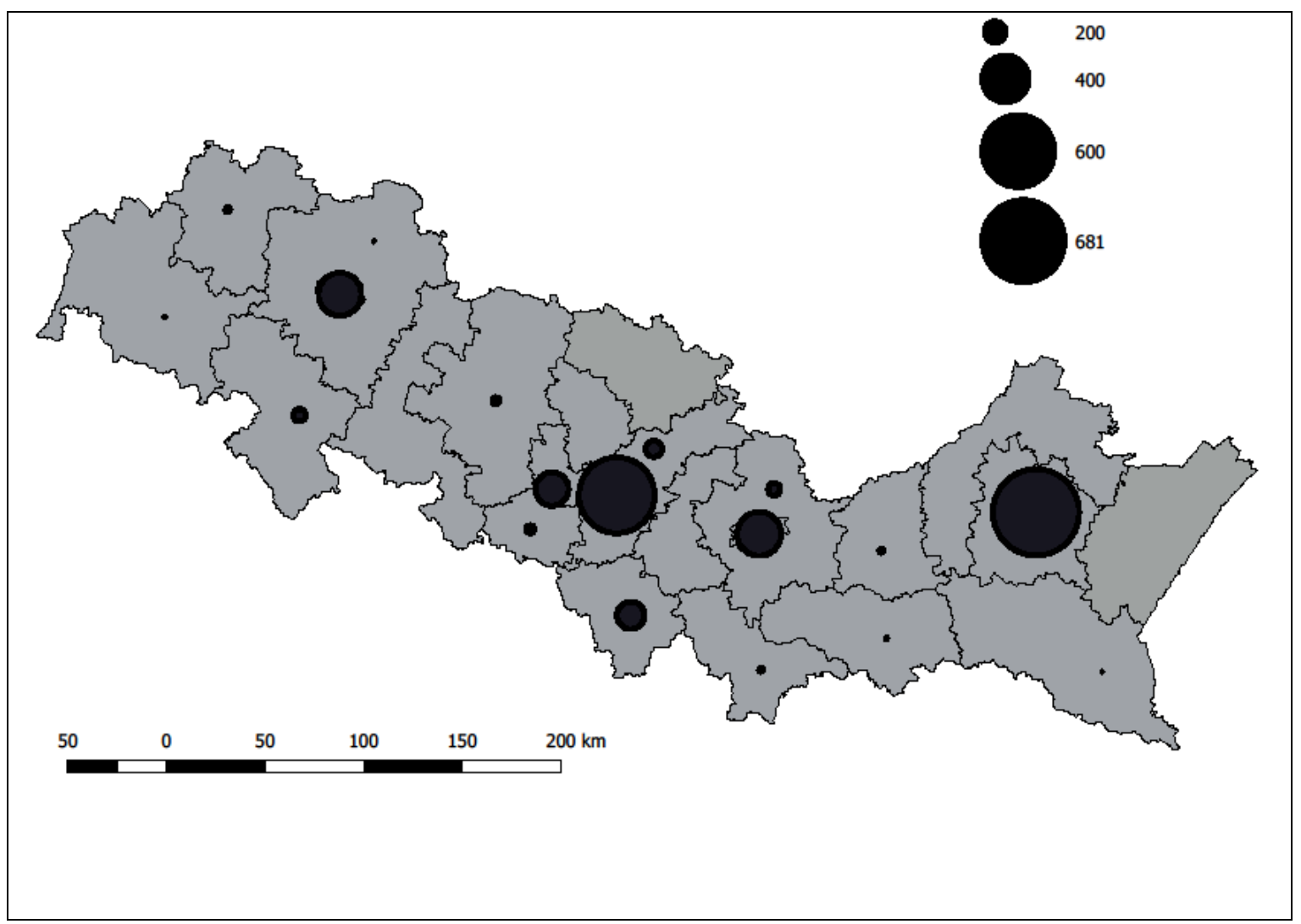

Source: compilation by authors

The distribution of clustering activity shown in Figure 1 is not surprising at the first sight. If to relate it to general economic activity, it shows that big cities seem to lead in the cluster category. A detailed look shows (see also Table 2), however, that the biggest value is achieved by Rzeszów, then there is Katowice, Kraków and Wrocław. The two next noticeable results are achieved by Gliwice and Bielsko-Biała. The position of Rzeszów should be appreciated, as the size, in terms of the number of inhabitants, of this city is comparable to Gliwice and Bielsko-Biała, and just about 1/4 of Krakow. The result of Rzeszów in this research could be anticipated, as the city is developing relatively fast for Polish standards and ranks high in many classifications. And the local leaders try to promote several branches of modern industry, with aviation as the most important. Katowice, on the other hand, is the heart of Górny Śląsk, which makes it a natural place for focusing advanced industrial activity, which explains its good position in the ranking. Kraków and Wrocław are the biggest cities in the ranking, yet they score moderately high in the rank. It seems that their development paths are more metropolitan, with less industry and more advanced services. What is more important, the main players in those cities are big business service corporations that do not seem to stimulate clustering that strongly. The clusters in Gliwice and Bielsko-Biała, even though not so strong as in Rzeszów, still highlight traditionally well developed industrial sector in those cities. The next two relatively important areas for clustering activity are the neighbourhoods of Krakow and Katowice (areas: Krakowski and Sosnowiecki), which can be classified as belonging to the agglomerations of their big cities. Wałbrzych is the last area with the clustering factor around 100, but considering the size of this city, this is not a very high result. 
In most of the rest of the areas, some clusters were also detected, yet the clustering factor was much lower. In some cases, however, no clustering activity was recognized.

The input data for the main analyses are shown in Table 2. For each area, the clustering factor was presented, together with the three corresponding variables described above.

Table 2: The main variables for correlation analyses (GDP in thousands of PLN, GVA for Polish average =100)

\begin{tabular}{|c|c|c|c|c|c|c|c|c|c|c|c|c|c|}
\hline Area & 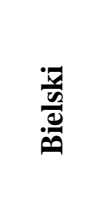 & 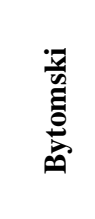 & 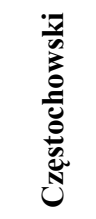 & 㲵 & 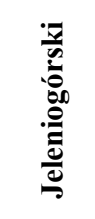 & 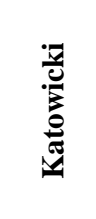 & 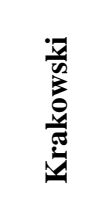 & 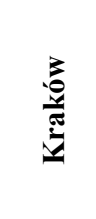 & 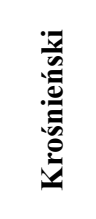 & 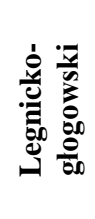 & 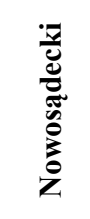 & 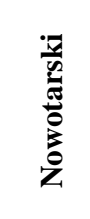 & 离 \\
\hline Cluster factor & 218 & 0 & 0 & 263 & 10 & 630 & 100 & 348 & 7 & 41 & 13 & 36 & 0 \\
\hline GVA p.w. & 102,5 & 97,4 & 90,6 & 116,7 & 102,9 & 111,1 & 82,2 & 109,1 & 64,6 & 151,7 & 67,9 & 67 & 85,4 \\
\hline GDP p.c. & 49,32 & 34,61 & 39,9 & 56,26 & 37,66 & 63,15 & 34,94 & 76,28 & 27,59 & 67,86 & 29,46 & 26,5 & 28,43 \\
\hline GDP growth & 22,62 & 13,56 & 15,89 & 29,41 & 16,94 & 26,58 & 17,79 & 36,29 & 10,8 & 28,28 & 12,46 & 10,82 & 11,65 \\
\hline Area & $\frac{\frac{\pi}{2}}{0}$ & 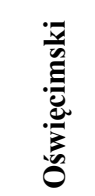 & 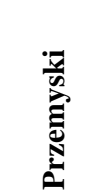 & 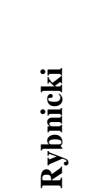 & 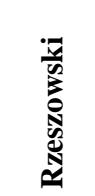 & 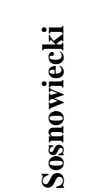 & 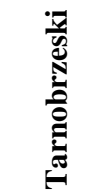 & 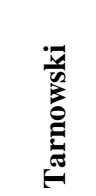 & $\frac{\frac{\pi}{4}}{2}$ & 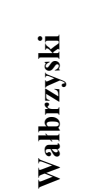 & 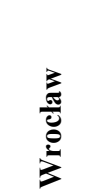 & 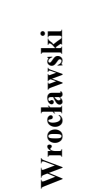 & \\
\hline Cluster factor & 58 & 0 & 0 & 64 & 756 & 92 & 51 & 35 & 0 & 99 & 338 & 11 & \\
\hline GVA p.w. & 99,9 & 93,2 & 61 & 107,5 & 85,2 & 111 & 78,2 & 73,7 & 113,1 & 97,2 & 112,8 & 106,5 & \\
\hline GDP p.c. & 43,51 & 36,12 & 24,64 & 41,06 & 41,7 & 43,76 & 34,3 & 30,58 & 59,42 & 34,5 & 76,98 & 47,62 & \\
\hline GDP growth & 19,03 & 14,79 & 8,476 & 16,21 & 20,89 & 17,72 & 14,53 & 13,3 & 22,76 & 14,34 & 41,44 & 26,71 & \\
\hline
\end{tabular}

Notes: GVA and GDP data for 2015, GDP growth for 2005-2015

Source: compilation by authors

The main results are presented in Table 3. They have been calculated with the usual $95 \%$ level of confidence (alpha $=0.05$ ).

Table 3: Pearson correlation coefficients of "cluster factor" and the variables

\begin{tabular}{cccc}
\hline & GVA per worker & GDP per capita & GDP growth \\
\hline $\mathrm{R}^{2}$ (correlation) & 0.20 & 0.49 & 0.53 \\
$\mathrm{t}$-stat & 0.99 & 2.69 & 2.99 \\
$\mathrm{t}$ - stat rejection area & $\leq-2.064,2.064 \geq$ & $\leq-2.064,2.064 \geq$ & $\leq-2.064,2.064 \geq$ \\
$\mathrm{p}$-stat & 0.33 & 0.013 & 0.006 \\
$\mathrm{p}$-stat rejection area & above 0.05 & above 0.05 & above 0.05 \\
$\mathrm{H} 1$ & Rejected & Accepted & Accepted \\
\hline
\end{tabular}

Note: GVA, GDP data for 2015, GDP growth for 2005-2015 period

Source: compilation by authors

The correlation analysis was supported by statistical tests (t-stat and p-stat), to ensure the statistical significance of the findings. In short, the results show that there is no correlation between the "clustering factor" that shows the level of clustering activity in the area and GVA per worker. In this case, the H1 hypothesis must be rejected. At the same time, the correlation between clustering and GDP per capita exists. The coefficient may be assessed as mild, yet it 
is statistically significant, as the tests show. The same is true for the GDP growth, with even better significance test results, which means that the H1 was accepted in those both cases. ${ }^{1}$

\section{Discussion}

Empirical studies on clusters usually use value-added data to explore possible externalities generated by those concentrations of companies. They often focus on one particular cluster and strictly defined industry, which may be called a micro approach. These papers contribute to the understanding of the way that clusters work. In order to investigate broader consequences of clustering, like its overall influence on total economic performance, more macro-oriented research is necessary. As a rule, the main objective of economic policy is a general improvement, which should not be limited to one particular cluster or industry. The results of this study show, that in the cases under investigation, no proof for positive externalities, understood as higher GVA, noticeable on the macro level, was found. And this is despite the fact, that both previous studies, as well as the understanding of the theory suggest, that such effects could be found.

On the other hand, the relations of clusters with GDP per capita and GDP growth were shown. Therefore, it can be stated that there is a connection between economic activity and clustering. Clusters seem often to be parts of a vivid economic landscape. Not generating extra GVA, they do not produce any additional profit margin for their economies. Yet, what the GDP represents is the size of the economy, which includes also the volume of sales of its companies. So one of the ways to understand the results is to suggest, that clustering may improve competitiveness through the amount of sale, even if not profitability.

This notion may be supported by referring to the very definition of a cluster. According to it, the clusters are build of geographically concentrated companies belonging to one, more or less widely understood industry. The companies in a cluster cooperate by subcontracting, specialize in different stages of the production process, and learn from each other. What they, however, also do, is competing. This competition, as it takes place on the business to business market, is to large extent based on pricing. This internal rivalry may cut down the profit margins so that no extra profits are possible in the industry. The other result of this process is, however, high competitiveness on the global market that the final goods produced in the cluster can achieve. Those goods may be offered by moderate prices, as the global competition demands it. Anyway, belonging to the cluster may enable producers to be competitive and to achieve big volumes of sales.

\section{Conclusion}

The study shows, on one hand, a correlation of clustering activity with GDP per capita and GDP growth. On the other hand, no correlation of this activity with the value added per working person was detected. The fact that clusters tend to be parts of a vivid economic landscape was this way shown. Similar results bring studies from other scholars, i.e. Kukalis (2010) conducted research on the micro level. Thirty-one years of performance data for 194

\footnotetext{
${ }^{1}$ What may be also useful is that at the preparation phase of this research another version of "cluster factor" was taken into consideration. It indicated the per capita ratio of this factor, but it also brought no statistically significant results in case of relation to GVA per worker.
} 
firms from pharmaceutical industries revealed no significant differences between clustered and non-clustered firms. In turn, McCann and Folta (2008) explored how different types of firms benefit from agglomeration. They showed, that not all firms gain from co-location and that industries with different internal capabilities capture different forms of geographical externalities. Yet, if there is a mechanism through which cluster activity improves the economic performance of a region, it is not connected with higher value added. This mechanism may, however, enable the companies from the cluster to be competitive on the global market and expand their volume of sales.

The obvious limitation of the study is the database of clusters that was created. A broader one, possibly based on all regions of Poland, could improve reliability. And, in contrast, a method of data gathering based on a high degree of industrial specialization would be also useful, though costlier and complex. Due to the fact, that the study was performed using data for Poland, with its specifics, probably a study for a country with a different economic structure would also bring interesting results.

\section{Acknowledgment}

This publication received financial support from the resources granted to the Faculty of Economics and International Relations of the Cracow University of Economics as part of the subsidy for the maintenance of the research potential.

Author Contributions: All authors listed have made a substantial, direct and intellectual contribution to the work, and approved it for publication.

Conflict of Interest Statement: The authors declare that the research was conducted in the absence of any commercial or financial relationships that could be construed as a potential conflict of interest.

\section{References}

Basu, S. \& Fernald, J. G. (1995). Are apparent productive spillovers a figment of specification error. NBER Working Papers, 5073, 1-35.

Beaudry, C. \& Schiffauerova, A. (2009). Who's right, Marshall or Jacobs? The localization versus urbanization debate. Research Policy, 38, 318-337.

Becattini, G. (1989). Sectors and/or Districts: Some Remarks on the Conceptual Foundation of Industrial Economics. In: Goodman, E. \& Bamford, J. \& Saynor, P. (eds.) Small firms and Industrial districts in Italy. London, UK: Routledge, 123-35.

Beciuini, G. \& Pisano, G. (2018). Knowledge integrators and the survival of manufacturing clusters. Journal of Economic Geography, 18(5), 1069-1089.

Belleflamme, P., Picard, P. \& Thisse, J. F. (2000). An economic theory of regional clusters. Journal of Urban Economics, 48, 158-184.

Callois, J. M. (2008). The two sides of proximity in industrial clusters: The trade-off between process and product innovation. Journal of Urban Economics, 63(1), 146-162.

Capello, R. (2009). Regional growth and local development theories: Conceptual evolution over fifty years of regional science. Géographie, Économie, Société, 1, 9-21.

Cruz, S. C. S. \& Teixeira, A. A. C. (2009). The evolution of the cluster literature: Shedding light on the regional studies - regional science debate. Regional Studies, 1-26.

Deming, D. J. (2017). The growing importance of social skills in the labor market. The Quarterly Journal of Economics, 132(4), 1593-1640. 
Eriksson, S. (2011). Promotion of company and local economic growth through clusters In: Karlsson, Ch. \& Picard, R. G. (eds.) Media Clusters. Spatial Agglomeration and Content Capabilities. Cheltenham, UK: Edward Elgar, 30-43.

GUS, Bank Danych Lokalnych, [Online], Available: https://bdl.stat.gov.pl/BDL/start.

Henderson, V. (1997). Externalities and industrial development. Journal of Urban Economics, 42(3), 449-470.

Hervas-Oliver, J., Lleo, M. \& Cervello, R. (2017). The dynamics of cluster entrepreneurship: Knowledge legacy from parents or agglomeration effects? The case of the Castellon ceramic tile district. Research Policy, 46, 73-92.

Jacobs, J. (1969). The Economies of Cities. New York, US: Random House.

Jevwegaga, H., Ade-adeniji, O., Ibidunni, A. S., Olokundun, M. A., Borishade, T. T., Falola, H. O., Obaoye, D. \& Ogunniyi, A. (2018). Role of SMEs' entrepreneurial activities and industrial clustering on SMEs' performance. Academy of Entrepreneurship Journal, 24, 1-7.

Komorowski, M. (2016). The seven parameters of media clusters: An integrated approach for local cluster analysis. International Journal of Media \& Cultural Politics, 12(2), 171- 191.

Kukalis, S. (2010). Agglomeration economies and firm performance: The case of industry clusters. Journal of Management, 36(2), 453-481.

Lucio, J. J., Herce, J. A. \& Goicdea, A. (2002). The effects of externalities on productivity growth in Spanish industry. Regional Science and Urban Economics, 32, 241-258.

Liu, Y., Lattemann, C., Xing, Y. \& Dorawa, D., (2019). The emergence of collaborative partnerships between knowledge-intensive business service (KIBS) and product companies: The case of Bremen, Germany. Regional Studies, 53(3), 376-387.

Lyu, Y., Liu, Q., He, B. \& Nie, J. (2017). Structural embeddedness and innovation diffusion: The moderating role of industrial technology grouping. Scientometrics, 111, 889-916.

McCann, B. T. \& Folta, T. B. (2008). Location matters: Where we have been and where we might go in agglomeration research. Journal of Management, 34(3), 532-565.

Marshall, A. (1890). Principles of economies. London, UK: Palgrave Macmillan.

Midelfart-Knarvik, K. H \& Steen, F. (1999). Self-reinforcing agglomerations? An empirical industry study. Scandinavian Journal of Economics, 101(4), 515-532.

Nachum, L. \& Keeble, D. (2003). Neo-Marshallian clusters and global networks. The linkages of media firms in central london. Long Range Planning, 36, 459-480.

Njøs, R. \& Jakobsen, S. E. (2016). Cluster policy and regional development: Scale, scope and renewal. Regional Studies, Regional Science, 3(1), 146-169.

Pandit, N. R., Cook, G. A. S., Wan, F., Beaverstock, J. V. \& Ghauri, P. N. (2018). The economies and diseconomies of industrial clustering: Multinational enterprises versus uninational enterprises. Management International Review, 1-33.

Pessoa, A. (2011). Externalities, clusters and economic growth: The cluster policy paradox. FEP Working Papers, 431, 1-25.

Porter, M. E. (2000). Location, competition, and economic development: Local clusters in a global economy. Economic Development Quarterly, 1, 15-34.

Press, K. (2006). A life cycle for clusters? The dynamics of agglomeration, change, and adaptation. PhysicaVerlag HD.

Qi, J., Zhenga, X. \& Guob H. (2019). The formation of Taobao villages in China. China Economic Review, 53, pp. 106-127.

Rodriguez-Victoria, O. E. \& Gonzalez-Loureiro, Puig, F. (2017). Economic competitiveness: Effects of clustering, innovation strategy and the moderating role of location in the Colombian hotel industry. Investigaciones Regionales, 39, 81-97.

Shaver, K. G. \& Scott, L. R. (2002). Person, process, choice: The psychology of new venture creation. In: Krueger, N. (eds.) Entrepreneurship. Critical perspectives on business and management. London, UK: Routledge, 334-361.

Vicente, J. (2018). Economics of clusters: A brief history of cluster theories and policy, Cham: Palgrave Macmillan. 